\title{
THE EFFECTS OF IMPLICIT VERSUS EXPLICIT INSTRUCTIONS TO TEACH REFUSAL STRATEGIES ON STUDENTS' SOCIOPRAGMATIC AND PRAGMALINGUISTIC COMPETENCE
}

\author{
Trifita Handayani \\ State Islamic College of Metro Lampung \\ E-mail : fitaorchid@gmail.com
}

\begin{abstract}
The purposes of the study were to explain the effects of implicit instruction on student's sociopragmatic competences, implicit instructions on students' pragmalinguistic competences, explicit instructions on students' sociopragmatic competences, explicit instructions on students' pragmalinguistic competences, the differences between implicit and explicit instructions on students' sociopragmatic competences, the differences between implicit and explicit instructions on student's pragmalinguistic competences, and the interaction between instructions with the students' sociopragmatic and pragmalinguistic competences. The study used quantitative research by using experimental factorial design $2 \times 2$. The data were taken from 80-second semester students at the English Language Education Study Program at STAIN. The result of the study revealed that the mean score of the post-test in implicit instruction on students' sociopragmatic was 80.000 while explicit 92.550. Meanwhile, the mean score of the post-test in implicit instruction on students' pragmalinguistic was 83.000 while explicit 95.5000 . It could be concluded that explicit has a better effect to teach refusal strategies than implicit instruction on students' sociopragmatic and pragmalinguistic competence based on the difference between the means score on implicit and explicit.
\end{abstract}

Keywords: implicit, explicit, refusal strategies, pragmatic competences.

\begin{abstract}
Abstrak
Tujuan Penelitian ini adalah untuk menjelaskan pengaruh pengajaran implicit pada kemampuan sosiopragmatik siswa, pengajaran implicit pada kemampuan pragmalinguistik siswa, pengajaran eksplicit pada kemampuan sosiopragmatik siswa, pengajaran eksplicit pada kemampuan pragmalinguistik siswa, perbedaan antara pengajaran implicit dan eksplisit pada kemampuan sosiopragmatik siswa, pengajaran eksplisit dan eksplisit pada kemampuan sosiopragmatik siswa, dan interaksi antara pengajaran dengan kemampuan sosiopramatik dan pragmalinguistik siswa. Penelitian ini menggunakan metode kuantitatif dengan eksperimen design factorial $2 \times 2$. Data di ambil dari 80 siswa semester dua
\end{abstract}


jurusan pendidikan bahasa inggris di STAIN. Hasil penelitian ini adalah nilai mean post-test di dalam pengajaran implicit pada kemampuan sosiopragmatik siswa adalah 80.00 sedangkan ekplisit 92.550. Sementara itu, nilai mean post-test di dalam pengajaran implicit pada kemampuan pragmalinguistik adalah 83.000 sementara eksplisit 95.5000. Dapat disimpulkan bahwa pengajaran eksplisit mempunyai pengaruh yang lebih baik untuk pengajaran strategi penolakan daripada pengajaran implicit pada kemampuan sosiopragmatik dan pragmalinguistik siswa berdasarkan perbedaan antara nilai mean pada implicit dan eksplisit.

Kata kunci: implicit, eksplisit, strategi penolakan, kemampuan pragmatik

\section{INTRODUCTION}

Semantics studies the meanings of words and sentences. Pragmatics studies how people comprehend and produce a speech act in social situations, usually in conversation. As a result, speakers must know many pragmatic elements in order to avoid inaccuracies and misunderstandings during communication. The communication has an important role in interacting with other people. We communicate effectively with our words, gestures, and tone of voice in a multitude of situations. Language is one of the means used by people to communicate. Through language, we can connect with other people and make sense of our experiences. The context in communication determines whether our words, our utterance are spoken or written, formal or informal, full of slang or technical jargon, off-color, colorful, or colorless. The social context in communication also affects our language or avoids the norms or rules of correctness that our speech deems appropriate to the occasion. When we utter the word or sentence, the speaker is characteristically performing several acts such as apologize when something goes wrong, promise for convincing something important, swear when we want to prove something, request or refuse something. The speech act of request or refusal is usually used in daily interaction. In other words, Beebe, et al. (1990:68) stated that the speech act of refusal occurs when a 
speaker directly or indirectly says 'no' to a request or an invitation. It can be said that the speech act of request is a direct or indirect order that the speaker asks the hearer to do something, while an act of refusal is a negative response to offer something, request, invitation, and suggestion. It is very difficult to refuse a request. The difficulties to refuse is also faced by students. It can be assumed that refusing a request will give a negative effect. Searle and Vandervken (1985) define the speech act of refusal as follows: "the negative counterparts to acceptances and consents are rejections and refusals. Just as one can accept offers, applications, and invitations, so each of these can be refused or rejected". In many cultures, how one says "no" is probably more important than the answer itself. Therefore, sending and receiving a message of "no" is a task that needs special skill. The interlocutor must know when to use the appropriate form and its function depending on each group and their cultural-linguistic values. The skills of refusing others' offers, requests, or invitations without hurting their feelings are very important to have since the "inability to say 'no' clearly has led many non-native speakers to offend their interlocutors ".

Referring to the problems proposed in this study, the statements of problems are formulated as follows:

1) How is the effect of implicit instructions to teach refusal strategies on student's sociopragmatic competences at the second-semester students of English Language Education at State Islamic College (STAIN) of Jurai Siwo Metro, Lampung?

2) How is the effect of implicit instructions to teach refusal strategies on student's pragmalinguistic competences at the second-semester students of English Language Education at State Islamic College (STAIN) of Jurai Siwo Metro, Lampung?

3) How is the effect of explicit instructions to teach refusal strategies on student's sociopragmatic competences at the second-semester students of English Language Education at 
State Islamic College (STAIN) of Jurai Siwo Metro, Lampung?

4) How is the effect of explicit instructions to teach refusal strategies on student's pragmalinguistic competences at the second-semester students of English Language Education at State Islamic College (STAIN) of Jurai Siwo Metro, Lampung?

5) How are the differences between implicit and explicit instructions to teach refusal strategies on student's sociopragmatic competences at the second-semester students of English Language Education at State Islamic College (STAIN) of Jurai Siwo Metro, Lampung?

6) How are the differences between implicit and explicit instructions to teach refusal strategies on student's pragmalinguistic competences at the secondsemester students of English Language Education at State Islamic College (STAIN) of Jurai Siwo Metro, Lampung?

7) How is the interaction between instructions with the students' sociopragmatic and pragmalinguistic competences at the second-semester students of English Language Education at State Islamic College (STAIN) of Jurai Siwo Metro, Lampung?

Regarding the statements of problems above, the objectives of this study are to explain the effects of implicit instructions to teach refusal strategies on student's sociopragmatic competences, to explain the effects of implicit instructions to teach refusal strategies on student's pragmalinguistic competences, to explain the effects of explicit instructions to teach refusal strategies on student's sociopragmatic competences, to explain the effects of explicit instructions to teach refusal strategies on student's pragmalinguistic competences, to explain the differences between implicit and explicit instructions to teach refusal strategies on student's sociopragmatic competences, to explain the differences between implicit and explicit instructions to teach refusal strategies on student's pragmalinguistic competences, to 
explain the interaction between instructions with the students' sociopragmatic and pragmalinguistic competences.

\section{Pragmatics Competence}

Levinson (1983:9) states that pragmatics is the study of those relations between language and context that are grammaticalized, or encoded in the structure of a language. It means that pragmatics is the meaning of language and context in communication with other people. We can see the other definition about pragmatic on Mey (1993:5) said that pragmatics starts out from the conception of language as being used and where the action is. It means that pragmatics is the concept of the language used to know the linguistic forms.

Pragmatic competence is one of the important parts of communicative competence proposed by Hymes (1972) and a revised model by Bachman and Palmer (1996). It means that pragmatic competence is an important thing in communicative competence.
One good definition of pragmatic competence is provided by Barron (2003:10) Pragmatic competence is understood as knowledge of the linguistic resources available in a given language for realizing particular illocutions, knowledge of the sequential aspects of speech acts and finally knowledge of the appropriate contextual use of the particular languages' linguistic resources. It means that pragmatic competence as the knowledge of linguistic resources of the learner in the target language and the knowledge of the appropriate contextual use of language.

\section{Sociopragmatics and}

\section{Pragmalinguistics Competence}

According to Kasper and over (2005:317), Sociopragmatic competency encompasses knowledge of the relationships between communicative action and power, social distance, and the imposition associated with a past or future event, knowledge of mutual rights and obligations, taboos, and conventional practices, or the social conditions and consequences of 
"what you do, when and to whom". It means that sociopragmatic competence is the ability to know the effect of context on strings of language events and to use language relates to the everyday social situation. Meanwhile, Kasper and Over add that (2005:317) pragmalinguistic competence comprises the knowledge and ability for use of conventions of means (such as the strategies for realizing speech acts) and conventions of the form (such as the linguistic forms implementing speech act strategies). It means that pragmalinguistic refers to speakers' ability to infer the communicative intention of the purpose of an utterance beyond the most literal meaning.

\section{Speech Act of Refusing}

Austin (1962) is acknowledged as the creator of speech act theory. Austin (1962) in Joan Cutting (2002:16) defined speech act as the actions performed in saying something. Speech act theory said that the action performed when an utterance is produced can be analyzed on three different levels.
1) A locutionary act is what is said, the form of the words uttered, the act of saying something.

2) An illocutionary act is what the speakers are doing with their words, the force or intention behind the words.

3) A perlocutionary act is the effect of the illocution on the hearer.

It means that a speech act is the utterances to describe something and the utterance is not only performed but also describes what is said. To be clear and make it easy to understand, we go to the example, I might say: It's hot here! (locution), meaning: I want some fresh air! (Illocution) and the perlocutionary effect might be that someone opens the window.

\section{Implicit and Explicit Instructions}

Ellis (2005, 2009) in Alhossaini, et al. (2014:184) stated that implicit instruction is referred to as a learning environment in which learners' attention is drawn to target forms without awareness and the focus of instruction is on meaning. It means that implicit instruction is the 
instruction about how to teach with explanations overtly but simply presents to the student to make their own conclusion and create their own concept. Meanwhile, according to DeKeyser (1995) in Alhossaini, et al. (2014:184) stated that explicit instruction involves learners in developing metalinguistic awareness of the target structure. It means that explicit instruction is the instruction about how to teach clearly and unambiguously explanation for the students.

\section{METHOD}

This study used quantitative research by using experimental factorial design $2 \times 2$. Singh, K. In Eryani, A. (2007:402) stated that the experiment is a research methodology used to establish causeand-effect relationships between the independent and dependent variables by means of manipulation of variables, control, and randomization. Meanwhile, Gay et al in Amarien, N. (2011: 272) stated that factorial designs are elaborations of single-variable experimental designs to permit investigation of two or more variables, at least one of which is manipulated by the researcher. In the factorial design, the two groups receive different treatment. This study adopted experimental groups, explicit and implicit, but without a control group.

In this study, Quantitative data were firstly calculated and represented by the frequency, mean scores and standard deviation of written DCT. Then the analysis of the responses of the written DCT which reflected the qualitative data was followed; other qualitative data were the classifications of written self-report. Finally, the interpretation of the entire analysis was reflected by involving both quantitative and qualitative data.

This study has applied to cluster random sampling. In cluster sampling, first, we divide the population into clusters (usually along geographic boundaries). Then we randomly select some clusters from all clusters formed to measure all units within sampled clusters in the end. So, the sample of this study was the second-semester students of English Language Education at State 
Islamic College (STAIN) of Jurai Siwo Metro. There were six classes, but I used four classes (PBI A, B, C, and D) and 20 students in each class. The instruments were used in this study are the form of test and questionnaire sheet. So, this study used pre-test and post-test in as measurement to measure the students. The quantitative data were collected through written DCT; while the qualitative data were obtained through the analysis of the responses of written DCT and the categorization of students' responses. The pretest was conducted before the treatment and the posttest was carried out immediately after the treatment. Data analysis is the process of analyzing data acquired from the result of the research. The scores in the written DCT administrating in the pretest and the posttest were quantitative data. The scores were analyzed by Statistic Package for the Social Sciences (SPSS 16.0) and could be used to answer the research questions respectively. The analysis of the responses of written DCT could be used as a qualitative answer. The data of study hypotheses 1 to 5 were analyzed by using an independent sample t-test of SPSS 16.0. Then, the data of study hypothesis 6 were analyzed by using two-way Analysis of Variance (ANOVA) of SPSS 16.0.

\section{FINDINGS AND DISCUSSION}

According to the first research question, the mean score of pre-test of implicit instruction on students' sociopragmatic competence is 58.1500 and the mean score of posttest of implicit instruction on students' sociopragmatic competence is 80.0000 .

Meanwhile, the value of sig (2-tailed) is the result of implicit instruction on students' sociopragmatic competence is 0.000 meaning that $\mathrm{H}_{0}$ is rejected and $\mathrm{H}_{\mathrm{a}}$ is accepted. So, there is a significant difference between pre-test and posttest in implicit instruction implemented to teach refusal strategies on students' sociopragmatic competence.

Dealing with the result of the first question, the strategy that has a better effect to teach refusal strategies on students' 
sociopragmatic competence is implicit instruction because the mean score of the pre-test is higher than post-test.

Related to the second research question, the mean score of pre-test of implicit instruction on students' pragmalinguistic competence is 60.1500 and the mean score of post-test of implicit instruction on students' pragmalinguistic competence is 83.0000 .

Meanwhile, the value of sig (2-tailed) is the result of implicit instruction on students' pragmalinguistic competence is 0.000 meaning that $\mathrm{H}_{0}$ is rejected and $\mathrm{H}_{\mathrm{a}}$ is accepted. So, there is a significant difference between pretest and post-test in implicit instruction implemented to teach refusal strategies on students' pragmalinguistic competence.

Dealing with the result of the second question, the instruction that has a better effect to teach refusal strategies on students' pragmalinguistic competence is implicit instruction because the mean score of the pre-test is higher than post-test.

In relation to the third research question, the mean score of the pre-test of explicit instruction on students' sociopragmatic competence is 60.7500 and the mean score of post-test of explicit instruction on students' sociopragmatic competence is 92.5500 .

Meanwhile, the value of sig (2-tailed) is the result of explicit instruction on students' sociopragmatic competence is 0.000 meaning that $\mathrm{H}_{0}$ is rejected and $\mathrm{H}_{\mathrm{a}}$ is accepted. So, there is a significant difference between pre-test and posttest in explicit instruction implemented to teach refusal strategies on students' sociopragmatic competence.

Dealing with the result of the third question, the instruction that has a better effect to teach refusal strategies on students' sociopragmatic competence is explicit instruction because the mean score of the pre-test is higher than post-test. 
In accordance with the fourth research question, the mean score of pre-test of explicit instruction on students' pragmalinguistic competence is 62.7500 and the mean score of post-test of explicit instruction on students' pragmalinguistic competence is 95.5000 .

Meanwhile, the value of sig (2-tailed) is the result of explicit instruction on students' pragmalinguistic competence is 0.000 meaning that $\mathrm{H}_{0}$ is rejected and $\mathrm{H}_{\mathrm{a}}$ is accepted. So, there is a significant difference between pretest and post-test in explicit instruction implemented to teach refusal strategies on students' pragmalinguistic competence.

To summarize the fourth question, the instruction that has a better effect to teach refusal strategies on students' pragmalinguistic competence is explicit instruction because the mean score of the pre-test is higher than post-test.

According to the fifth research question, the mean score of the posttest of students' sociopragmatic competence treated by using implicit instruction is 80.0000 and the mean score of posttest of students' sociopragmatic competence treated by explicit instruction is 92.5500 .

Meanwhile, the value of sig (2-tailed) in posttest results of students' sociopragmatic competence treated by using implicit instruction is 0.000 and using explicit instruction is 0.000 meaning that $\mathrm{H}_{0}$ is rejected and $\mathrm{H}_{\mathrm{a}}$ is accepted. So, there is a significant difference in the effect between implicit and explicit instruction on students' sociopragmatic competence.

To sum up the fifth research question, the students' sociopragmatic competence treated by explicit instruction improve better than the students' sociopragmatic competence treated by using implicit instruction because the mean score of students' sociopragmatic competence treated by explicit instruction is higher than the students' sociopragmatic competence treated by implicit instruction.

Related to the sixth research question, the mean score of posttest 
of students pragmalinguistic competence treated by using implicit instruction is 83.0000 and the mean score of posttest of students' pragmalinguistic competence treated by explicit instruction is 95.5000 .

Then the value of sig (2tailed) in posttest results of students' pragmalinguistic competence treated by using implicit instruction is 0.000 and using explicit instruction is 0.000 meaning that $\mathrm{H}_{0}$ is rejected and $\mathrm{H}_{\mathrm{a}}$ is accepted. So, there is a significant difference in the effect between implicit and explicit instruction on students' pragmalinguistic competence.

To conclude the sixth research question, the students' pragmalinguistic competence treated by explicit instruction improve better than the students' pragmalinguistic competence treated by using implicit instruction because the mean score of students' pragmalinguistic competence treated by explicit instruction is higher than the students' pragmalinguistic competence treated by implicit instruction.
Related to the seventh research question, the P-value of instructions is 0.000 . It is lower than $\alpha 0.05$ meaning that $\mathrm{H}_{0}$ is rejected and $\mathrm{H}_{\mathrm{a}}$ is accepted. It indicates that it is significant of effect difference between implicit and explicit instructions on the result of the posttest.

The P-value of pragmatic competence is 0.000 . It is lower than a 0.05 meaning that $\mathrm{H}_{0}$ is rejected and $\mathrm{H}_{\mathrm{a}}$ is accepted. It indicates that there is a significant effect difference between students' sociopragmatic and pragmalinguistic on the result of the posttest.

The P-value of instructions pragmatic competences is 0.009 . It is lower than $\alpha 0.05$ meaning that $\mathrm{H}_{0}$ is rejected and $\mathrm{H}_{\mathrm{a}}$ is accepted. It indicates that there is an interaction between instructions and pragmatic competence.

From the whole result, it can be concluded that there is no interaction among instructions and students' pragmatic competences to teach refusal strategies on students' sociopragmatic and pragmalinguistic competence. 


\section{CONCLUSIONS}

Dealing with the first finding, the implicit instruction that has a better effect to teach refusal strategies on students' sociopragmatic competence because the mean score of the pre-test is higher than the post-test score after the treatment.

Relating to the second finding, the implicit instruction that has a better effect to teach refusal strategies on students' pragmalinguistic competence because the mean score of the pretest is higher than the post-test score after the treatment.

Concerning on the third finding, the explicit instruction that has a better effect to teach refusal strategies on students' sociopragmatic competence because the mean score of the pre-test is higher than the post-test score after the treatment.

Referring to the fourth finding, the explicit instruction that has a better effect to teach refusal strategies on students' pragmalinguistic competence because the mean score of the pre- test is higher than the post-test score after the treatment.

In line with the fifth finding, implicit and explicit instruction is effect to teach refusal strategies on students' sociopragmatic competence. But, Explicit much better than implicit instruction because there is a significant difference of effect between implicit and explicit instruction on students' sociopragmatic competence. That is, there was a difference from the scores between the pretest and posttest in implicit and explicit instruction. The difference tended to be a positive direction because the achievements of the posttest were much better than of the pretest. As to the comparison of the two instructions, the explicit instruction is instruction better than the implicit instruction for teaching English refusals. The implicit instruction is an effective method for the instruction of English refusals, but it is not as good as the explicit one. The major reason is a very clear and systematic teaching method in explicit instruction; while the teaching method in the implicit 
group is not as clear and systematic as the explicit one.

Looking back to the sixth finding, implicit and explicit instruction is effect to teach refusal strategies on students' pragmalinguistic competence. But, Explicit much better than implicit instruction because there is a significant difference of effect between implicit and explicit instruction on students' pragmalinguistic competence. The reason is that the learners were heavily influenced by culture and habit. However, qualitatively, the performances in refusals to invitations, suggestions, offers, and requests in the explicit group were better than those in the implicit group. The reasons could be that the students' knowledge in these types in the explicit group was better than that in the implicit group. Due to the salient features in the explicit instruction, the performances in quality of information, level of formality and strategy choices in Explicit Group were better than Implicit Group. In terms of the effect, the achievement of explicit instruction was better than the implicit instruction. Comparing to the pretest, the scores in the posttest improved, the good teaching effect and students' interest in learning can account for this result.

Dealing with the seventh finding, there is no interaction among instructions and students' sociopragmatic and pragmalinguistic competence to teach refusal strategies. 


\section{REFERENCES}

Amarien, N. 2011. Interlanguage Pragmatics: A Study of the Refusal Strategies of the Indonesian Speakers Spaking English. Teaching English as a Foreign Language in Indonesia (TEFLIN) Journal. Available on http://journal.teflin.org/index.p hp/teflin/article/view/178/66 Access on 8th September 2015

Austin J. L. 1962. How to do Things with Words. Oxford: Oxford University Press.

Barron, Anne. 2003. Acquisition in Interlanguage Pragmatics, Amsterdam: John Benjamin's Publishing Company.

Beebe, L.M., T. Takahshi, and R. Uliss-Weltz. 1985. Pragmatic transfer in ESL refusals. Paper presented at the Second Research Forum, UCLA. To Appear in On the Development of Communicative Competence in a Second Language, eds. R. C. Scarcella, E. Andersen, and S. C. Krashen Rowley, MA: Newbury House.

Creswell, John W. Research Design. Qualitative, Quantitative, and Mixed Methods Approaches. Third edition. California: SAGE Publications, Inc.

Cutting, Joan. 2002. Pragmatics and Discourse. A resource Book for Students. New York: Routledge.
Ellis, R.. 2008. The Study of Second Language Acquisition. Oxford: Oxford University Press.

Eryani, A. 2007. Refusal Strategies by Yemeni EFL Learners. The Asian EFL Journal. Volume 9, Number 2. Available on http://www.asian-efljournal.com/June_2007_EBoo k_editions.pdf Access on 8th September 2015

Eslami-Rasekh, Z. 2004. Learning the Pragmatic Awareness of Language Learners. English Language Teaching Journal. Volume.59, Issue 3,pages 199 208.

http://dx.doi.org/10.1093/elt/cc i039 Access on 8th September 2015

Fakher Ajabshir, Zahra. 2014. The Effect of Implicit and Explicit Types of Feedback on Learners' Pragmatic Development. International Conference on Current Trends in ELT. Procedia - Social and Behavioral Sciences. Volume 98. Pages $463-471$ www.sciencedirect.com Access on 8th September 2015

Hymes, Dell. 1977. Foundations in Sociolinguistics. London: Tavistock Publications.

Kasper, G., Rose, K.R. 2002. Pragmatic Development in a Second Language. Mahwah, NJ: Blackwell. 
Kasper, G., Rose, K.R. Pragmatics in Language Teaching (New York: Cambridge University Press): 200-22

Levinson, Stephen C. 1983. Pragmatics. New York: Cambridge University Press.

Mey, Jacob L. 1993. Pragmatics. An Introduction. Oxford: Blackwell Publishers.

Searle, John R. 2010b. Speech Act Performance: Theoretical, Empirical and Methodological Issues. Amsterdam: John Benjamins. 